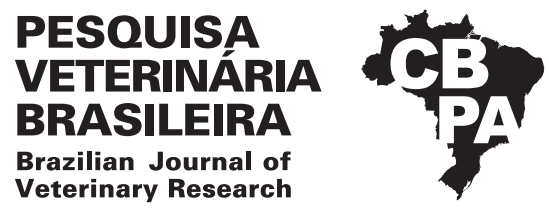

Pesq. Vet. Bras. 39(8):573-579, August 2019 DOI: $10.1590 / 1678-5150-P V B-6248$

Original Article

ISSN 0100-736X (Print)

ISSN 1678-5150 (Online)

\title{
Outbreaks of nutritional cardiomyopathy in pigs in Brazil ${ }^{1}$
}

\author{
Raquel A.S. Cruz ${ }^{2}$ (D), Daniele M. Bassuino², Matheus O. Reis², Cláudio J.M. Laisse², \\ Saulo P. Pavarin ${ }^{2}$ (D), Luciana Sonne ${ }^{2}$, Alexandre M. Kessler ${ }^{3}$ and David Driemeier ${ }^{2 *}$ (D)
}

\begin{abstract}
Cruz R.A.S., Bassuino D.M., Reis M.O., Laisse C.J.M., Pavarini S.P., Sonne L., Kessler A.M. \& Driemeier D. 2019. Outbreaks of nutritional cardiomyopathy in pigs in Brazil. Pesquisa Veterinária Brasileira 39(8):573-579. Setor de Patologia Veterinária, Faculdade de Veterinária, Universidade Federal do Rio Grande do Sul, Av. Bento Gonçalves 9090, Porto Alegre, RS 91540-000, Brazil. E-mail: davetpat@ufrgs.br

Dilated cardiomyopathy (DCM) is a condition that affects the myocardium, seldom reported in pigs. The DCM is characterized by ventricular dilation, which results in systolic and secondary diastolic dysfunction and can lead to arrhythmia and fatal congestive heart failure. This study described the clinical, pathological, chemical and toxicological findings of nutritional dilated cardiomyopathy (DCM) in nursery pigs through natural and experimental studies. Naturally occurring cases of DCM in three swine farms were investigated through necropsy (fourteen pigs), microscopic, virological, chemical and toxicological exams for the detection of the etiology. The experimental study was conducted with nine 40 days-old piglets, which were divided into three groups of three piglets each. Group 1 was fed with the suspected diet of the naturally occurring cases, Group 2 with half of the suspected diet and half of a control diet, and Group 3 received only the control diet. Clinical signs were recorded. All pigs were submitted of euthanized, necropsie and collection sample for laboratories exams, after 15 days of experiment onset. At the necropsy, all naturally occurring cases had bilateral cardiac dilatation associated to hepatic enhanced lobular pattern (nutmeg liver) and lungs edema. Microscopically, the heart revealed severe hypertrophy and vacuolization of cardiomyocytes, as well as myofiber disarray. Feed analysis revealed low-quality standard soybean meal. After the suspected feed was replaced, clinically ill pigs recovered, and mortality ceased. At the experimental study, two piglets from Group 1 had cough, dyspnea and diarrhea. At the necropsy, these animals had similar gross and microscopic lesions to the natural cases. The nutritional DCM in pigs may be associated to the diet with low-quality soybean meal, as it was further confirmed through an experimental study.
\end{abstract}

INDEX TERMS: Outbreak, nutritional cardiomyopathy, pigs, Brazil, swine, cardiomyopathy, heart, diet, soyben meal, heart failure.

\begin{abstract}
RESUMO.- [Surtos de cardiomiopatia nutricional em suínos no Brasil.] Cardiomiopatia dilatada (CMD) é uma condição que afeta o miocárdio, raramente relatada em porcos. A DCM é caracterizada por dilatação ventricular, que resulta em disfunção sistólica e disfunção diastólica

\footnotetext{
${ }^{1}$ Received on March 12, 2019.

Accepted for publication on April 1, 2019.

${ }^{2}$ Setor de Patologia Veterinária, Faculdade de Veterinária, Universidade Federal do Rio Grande do Sul (UFRGS), Av. Bento Gonçalves 9090, Porto Alegre, RS 91540-000, Brazil. *Corresponding author: davetpat@ufrgs.br

${ }^{3}$ Laboratório de Ensino Zootécnico, Universidade Federal do Rio Grande do Sul (UFRGS), Av. Bento Gonçalves 9090, Porto Alegre, RS 91540-000.
}

secundária e pode levar a arritmias e insuficiência cardíaca congestiva fatal. Este estudo descreve os achados clínicos, patológicos, químicos e toxicológicos da CMD em suínos de creche através de estudos naturais e experimentais. Investigaram-se três granjas com surtos de mortalidade por CMD através de exames de necropsia (catorze suínos), microscópicos, virológicos, químicos e toxicológicos para a deteç̧ão da etiologia. 0 estudo experimental foi conduzido com nove leitões de 40 dias de idade, divididos em três grupos de três leitões cada. 0 grupo 1 foi alimentado com a dieta suspeita dos casos naturais; o 2 com metade da dieta suspeita e metade de dieta controle; e o 3 recebeu apenas 
a dieta controle. Sinais clínicos foram registrados. Todos os suínos foram submetidos a eutanásia, necropsia para a coleta de amostras para exames laboratoriais após 15 dias do início do experimento. Na necropsia, todos os leitões dos casos naturais apresentavam dilatação cardíaca bilateral associada a padrão lobular hepático aumentado (fígado de noz-moscada) e edema pulmonar. Microscopicamente, o coração revelou hipertrofia severa e vacuolização de cardiomiócitos, bem como desordem de miofibras. A análise da ração demonstrou que o farelo de soja apresentava baixa solubilidade o que indica baixa qualidade. Após a substituição da ração suspeita, os porcos clinicamente doentes recuperaram e a mortalidade cessou. No estudo experimental, dois leitões do grupo 1 apresentaram tosse, dispneia e diarreia. Na necropsia, esses animais apresentavam lesões macroscópicas e macroscópicas similar aos casos naturais. A CMD nutricional em suínos pode estar associado à dieta com farelo de soja de baixa qualidade, como foi confirmado através de um estudo experimental.

TERMOS DE INDEXAÇÃO: Surtos, cardiomiopatia nutricional, suínos, Brasil, coração, dieta, farelo de soja, insuficiência cardíaca.

\section{INTRODUCTION}

Cardiomyopathy (CM) refers to conditions that cause structural and/or functional abnormalities in the myocardium with concomitant dilatation or hypertrophy of one or both ventricles and possibly all four chambers of the heart (Richardson et al. 1996, Elliott et al. 2008, Harvey \& Leinwand 2011). It affects humans and domestic animals and may be categorized into three morphologic forms: dilated (congestive), hypertrophic and restrictive (Richardson et al. 1996, Elliott et al. 2008).

Dilated cardiomyopathy (DCM) is a primary or secondary myocardial disorder of characterized by the reduced contractility and ventricular dilation involving the left or both ventricles (O'Grady \& O'Sullivan 2004, Miller \& Gal 2017). It is an important cause of congestive heart failure in animals (Czarnecki 1984, Edwards 1987, Lobo \& Pereira 2002, O'Grady \& O'Sullivan 2004, Miller \& Gal 2017, Collins et al. 2015).

DCM is been studied in many species, but it has been extensively studied in dogs (Sisson et al. 1999, Lobo \& Pereira 2002, O'Grady \& O'Sullivan 2004). One form of DCM known as "round heart disease" has been discovered in turkeys, and this form of DCM does not have a well-defined etiopathogenesis (Czarnecki 1984, Stenzel et al. 2008). In cattle, DCM with a familial genetic origin has been determined to be an autosomal recessive inherited disease (Miller \& Gal 2017). In swine, DCM has been associated with gossypol poisoning, fumonisin toxicosis and cardiomyopathy with an undetermined origin (Loynachan 2012, Sobestiansky 2012, Collins et al. 2015).

DCM causes ventricular dilation, systolic dysfunction, and secondary diastolic dysfunction, which may progress to congestive heart failure, arrhythmias, and eventually lead to death (Sisson et al. 1999, Sisson \& Thomas 1999). Morphologically, myocardium is thinner, with dilated and flaccid cardiac chambers and, thus is weakened and unable to pump blood efficiently (Edwards 1987, Keene et al. 1994, O'Grady \& O'Sullivan 2004).

The aim of this study was to describe the clinical, pathological, chemical and toxicological findings of nutritional DCM in nursery pigs through natural and experimental studies.

\section{MATERIALS AND METHODS}

Natural cases: clinical, epidemiological and histopathological features. From 2011 to 2014 eight porcine samples of multiple organs from three farms in Southern Brazil with high mortality rates of nursery-growing pigs Paraná (A), Rio Grande do Sul (B), and Mato Grosso do Sul (C)] had microscopical lesions consistent with congestive heart failure. On-site visits to the three farms were performed and data regarding the clinical signs and epidemiology were obtained with the clinician veterinarians. Fourteen piglets with clinical signs of cough and dyspnea from A (4 piglets), B (6) and farm C (4) were subjected to euthanasia followed by necropsy. Multiple tissue samples were collected, fixed in 10\% neutral buffered formalin, processed for histopathology, and stained with hematoxylin and eosin (HE). Heart sections were also stained with periodic acid-Schiff (PAS) and Masson's trichrome (MT) to characterize morphologically the cardiac injury. Lung sections were also stained with Perl's Prussian blue stain to highlight the congestive heart failure lesions (heart failure cells).

Experimental study. The experimental study was conducted during 15 days with nine 40 -day-old piglets ( $15 \mathrm{~kg}$ of weight), which were further divided into three groups: 1 (suspected feed), 2 (50\% suspected feed $+50 \%$ control feed) and 3 (100\% control feed). The suspected feed was collected at the farm B, and was formulated with corn, soybean meal and commercial premix. The animals received their respective diet and water ad libitum for the experimental period, were daily monitored and weekly weighed.

All nine pigs were humanely euthanized as required by current legislation under the approval of the UFRGS Ethics and Animal Experimentation Committee (approval protocol number 29467). The carcasses were weighed and at necropsy multiple tissues, were collected and fixed in $10 \%$ buffered formalin. The whole heart from each pig was collected and weighed after the blood was drained. The heart weight/body weight (HW:BW) coefficient was then determined (Turk 1983, Richardson et al. 1996).

Chemical and toxicological analysis. Liver samples collected from the necropsied pigs of farm $B$ and from the experimental study were frozen at $-20^{\circ} \mathrm{C}$ to evaluate vitamin $\mathrm{E}$ and selenium levels. Liver and heart samples previously fixed in $10 \%$ formalin from piglets of farms B and C and from the experimental groups were used to determine the levels of other minerals. Feed samples from farms $\mathrm{A}$ and $\mathrm{B}$ were collected for chemical and toxicological analyses according to the substances and methodologies shown in Table 1.

A protein analysis (proteinogram) was performed on the feed sample from farm B, with the dosage of the following amino acids: alanine, arginine, aspartic acid, glycine, isoleucine, leucine, glutamic acid, lysine, cysteine, methionine, phenylalanine, tyrosine, threonine, tryptophan, proline, valine, histidine, and serine.

Molecular analysis. Fixed and paraffin-embedded myocardium samples of two pigs from each outbreak and from the experiment were subjected to molecular analysis for the detection of the major viral agents responsible for heart lesions in pigs: porcine circovirus, porcine parvovirus, influenza A, pestivirus and enterovirus, according to previously described protocols (Opriessnig et al. 2003, Vilcek et al. 2003, Vecchia et al. 2012).

\section{RESULTS}

\section{Natural cases: clinical features and gross findings}

Three outbreaks of acute respiratory failure, with dyspnea, cough, fatigue, and anorexia, followed by death within days in nursery-growing pigs (30-70 days-old) were observed 
Table 1. Chemical and toxicological dosages in liver, heart, soybean meal and feed samples of the piglets with dilated cardiomyopathy

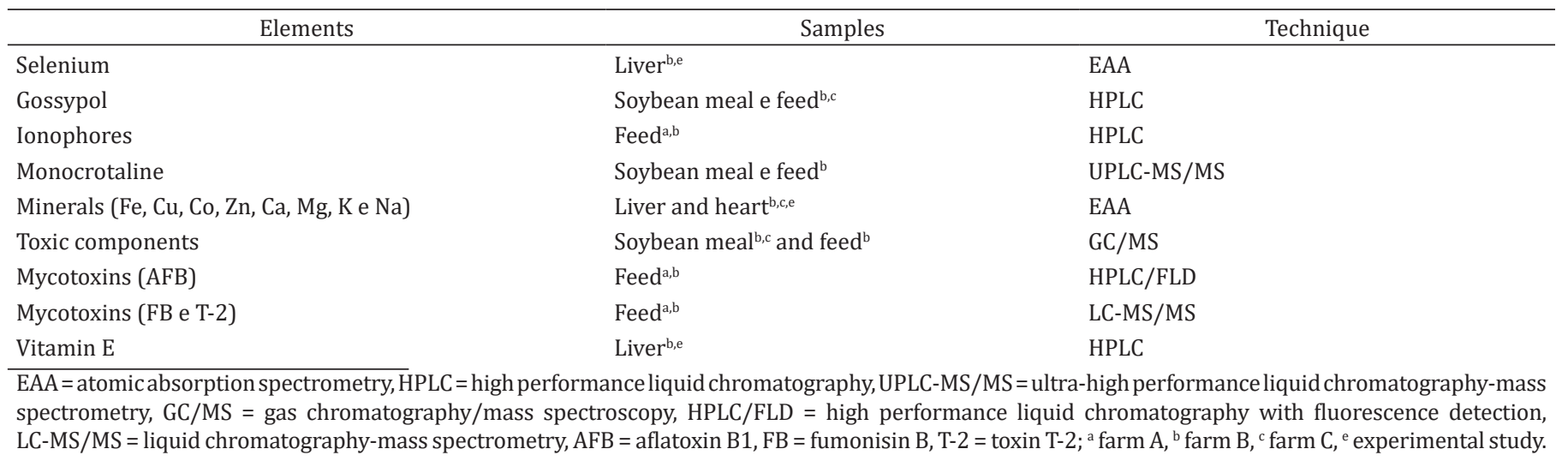

from March-June of 2011 and 2014. The farms were located in Paraná state (A), Rio Grande do Sul state (B) and Mato Grosso do Sul state (C), and during the outbreaks a total of 183 pigs died ( 60 at $A, 53$ at $B$ and 80 at C). The pigs were treated unsuccessfully with antibiotics. Mortality levels ranged from 2 to $10 \%$, which were considered above average within the farms.

Feed analysis from $\mathrm{B}$ and $\mathrm{C}$ revealed low-quality standard soybean meal, with a low urea activity index of 0.03 and 0.04 (reference values - RV: 0.05 to 0.2 ) and solubility analysis showed values between 50 and 60\% (RV: 70-80\%) (Berthol et al. 2001). In all three farms, after the suspected feed was replaced, clinically ill pigs recovered, and mortality ceased.

At necropsy, all 14 pigs had enlarged hearts which occupied almost the entire sternal surface (Fig.1A). The abdominal and thoracic cavity and the pericardial sac were filled with variable amounts of translucent fluid (ascites, hydrothorax and hydropericardium) (Fig.1B). In addition, there was severe hepatomegaly with an enhanced lobular pattern (nutmeg liver) (Fig.1C). The enlarged heart had a globular appearance (Fig.1D) with severe bilateral ventricular dilation and intraventricular clotted blood (Fig.1E). In some pigs from farm $C$, there was hepatic atrophy, with marked chronic lesions. The spleen was moderately enlarged and exuded blood at the cut surface. The lungs were not collapsed, and there was mild to moderate interlobular edema.

\section{Experimental study: clinical features and gross findings}

In the experimental study, one piglet from Group 1 had cough on the 8th day of feed consumption and severe dyspnea on the 13th day. Another piglet from the same group had diarrhea, with orange-stained feces on the 7 th day of the experiment. The remaining pigs did not show any clinical abnormalities. Both piglets from Group 1 that presented clinical signs had similar gross lesions to those found in natural cases, with a mild amount of fluid in the abdominal and thoracic cavity, moderate bilateral ventricular dilatation (Fig.1F), and a nutmeg liver. The HW/BW evaluation of these two pigs $(0.73 \%$ and $0.86 \%)$ revealed a significant difference when compared to the control pigs (average of $0.53 \%$ ). Piglets from Group 2 and 3 did not present any gross lesions.
Natural cases and experimental study: histological findings

The histological examination of the myocardium in all the pigs of natural cases revealed marked cardiomyocyte hypertrophy and attenuated wavy fibers in the myocardium, shown in Figure 2A, and the heart from a control pig is shown in Figure 2B. Additionally, in two pigs (farms A and B), multifocal thrombosis in the myocardium, mild multifocal fibrinoid necrosis of blood vessel walls, and a mild multifocal infiltrate of lymphocytes in the epicardium and myocardium were observed. The liver had moderate to marked congestion, necrosis, and degeneration of the centrilobular hepatocytes (nutmeg liver) (Fig.2C,D). The lungs revealed moderate interlobular septal edema (Fig.2E) and a moderate number of hemosiderin-laden macrophages (heart failure cells) within the alveoli (Fig.2F), which were highlighted through Perl's Prussian blue stain. Fibrinoid necrosis of the vessel walls was highlighted through PAS stain, which also revealed lesions in the lymph nodes in one pig at farm $A$, and in the spleen and brain in two pigs at farm B.

Only two piglets from Group 1 that displayed clinical signs and gross lesions of DCM had microscopical abnormalities. These were similar to those observed in natural cases. Piglets from Group 2 and 3 did not present any microscopic lesions.

\section{Chemical and toxicological analyses}

Selenium values were below $2.16 \mu \mathrm{g} / \mathrm{kg}$ (RV: 0.1 to $2.9 \mu \mathrm{g} / \mathrm{kg}$ (Pallarés et al. 2002) in the analyzed samples of all the pigs for the natural and experimental cases. Vitamin E values in the liver of the pigs both from natural and experimental cases were below $8.55 \mu \mathrm{g} / \mathrm{kg}$ in all pigs (RV: $3.8-10 \mu \mathrm{g} / \mathrm{kg}$ ), except

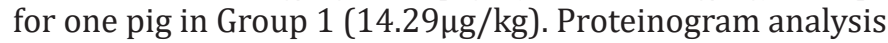
had values within the reference range.

All of the piglets with DCM in the natural and experimental cases had high magnesium levels $(600-800 \mu \mathrm{g} / \mathrm{kg})$ in the myocardium compared to the control animals $(300-400 \mu \mathrm{g} / \mathrm{kg})$. The iron levels in the liver were lower in affected animals from the Experimental Group (113-120 $\mu \mathrm{g} / \mathrm{kg})$ than in animals in the Control Group (145-150 $\mu \mathrm{g} / \mathrm{kg})$.

Gossypol, monocrotaline and ionophores were not detected in feed samples from B and C. Additionally, mycotoxin levels in the feed were below the toxic threshold $(<10 \mathrm{mg} / \mathrm{kg}$ for fumonisins and $<50 \mu \mathrm{g} / \mathrm{kg}$ for aflatoxin) (Sobestiansky 2012) 

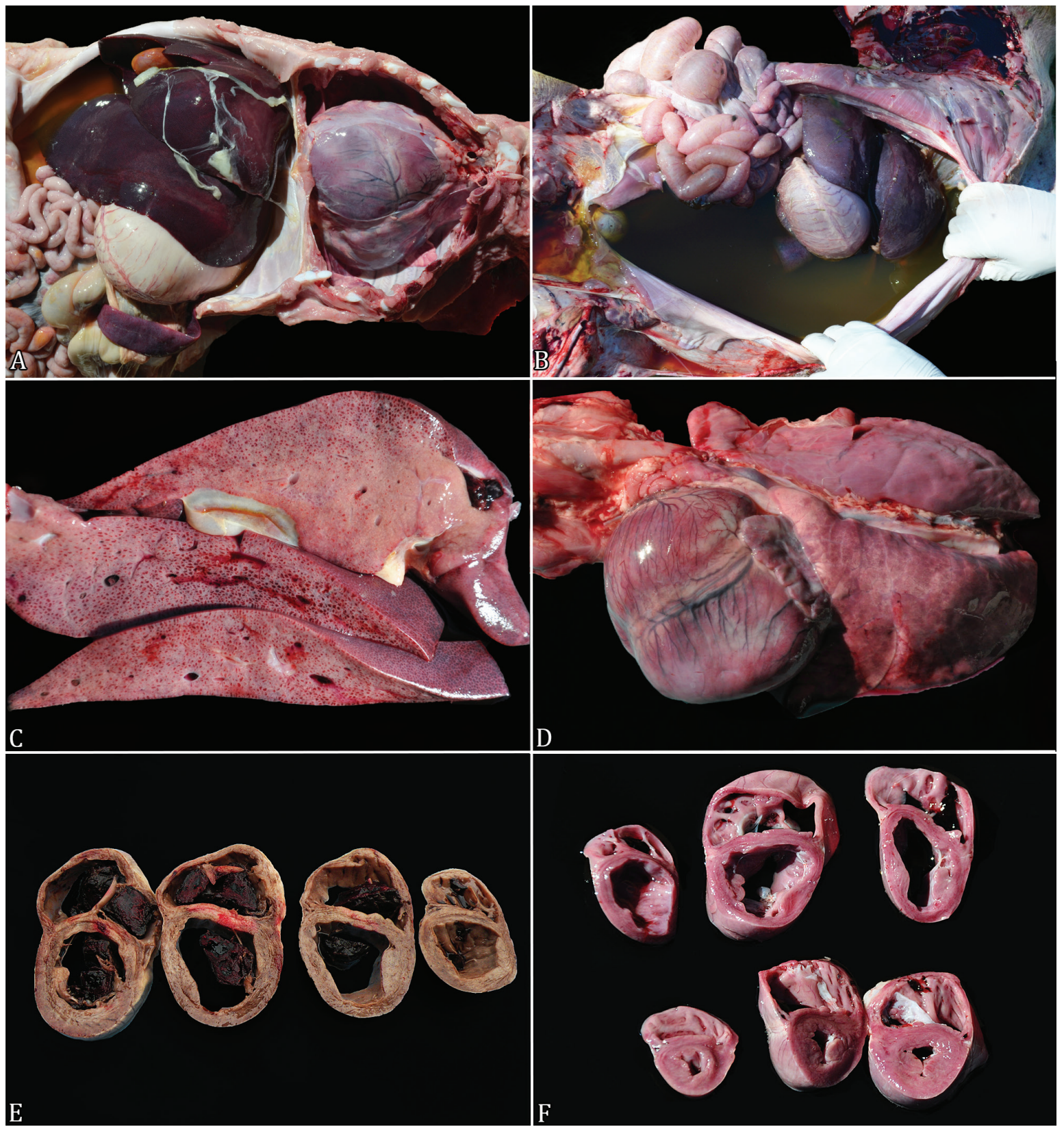

Fig.1. Gross features of nutritional dilated cardiomyopathy in pigs in Brazil. (A) The heart was markedly enlarged and occupied most of the thoracic cavity. There was also moderate ascites and a severe hepatomegaly. (B) The abdominal cavity was filled by abundant amount of translucent fluid (ascites). (C) The enlarged liver had an enhanced lobular pattern at the cut surface. (D) Natural cases had a severely enlarged heart with a globular appearance. (E) At the cut surface, there was severe bilateral ventricular dilation and intraventricular clotted blood. (F) Transversal sections of the heart of one piglet from the experimental cases displayed severe bilateral ventricular dilatation (above) and. the heart of a normal control pig is presented (below).

\section{Molecular analysis}

Porcine circovirus, porcine parvovirus, influenza A, pestivirus and enterovirus molecular analysis from heart samples of natural and experimental cases yielded negative results.

\section{DISCUSSION}

The diagnosis of congestive heart failure by nutritional DCM in pigs was obtained by the association of the pathological, epidemiological, and experimental findings. DCM in pigs has been linked to poisoning by gossypol, fumonisin toxicosis and unknown causes (Loynachan 2012, Sobestiansky 2012, Collins et al. 2015, Miller \& Gal 2017). Which were ruled out in this study through the chemical and toxicological tests of the feeds from B and C. Magnesium levels in the heart were higher in piglets with DCM (both natural and experimental pigs) than in the Control Group, which may be related to the occurrence of cardiac alterations (Korpela 1991). However, 


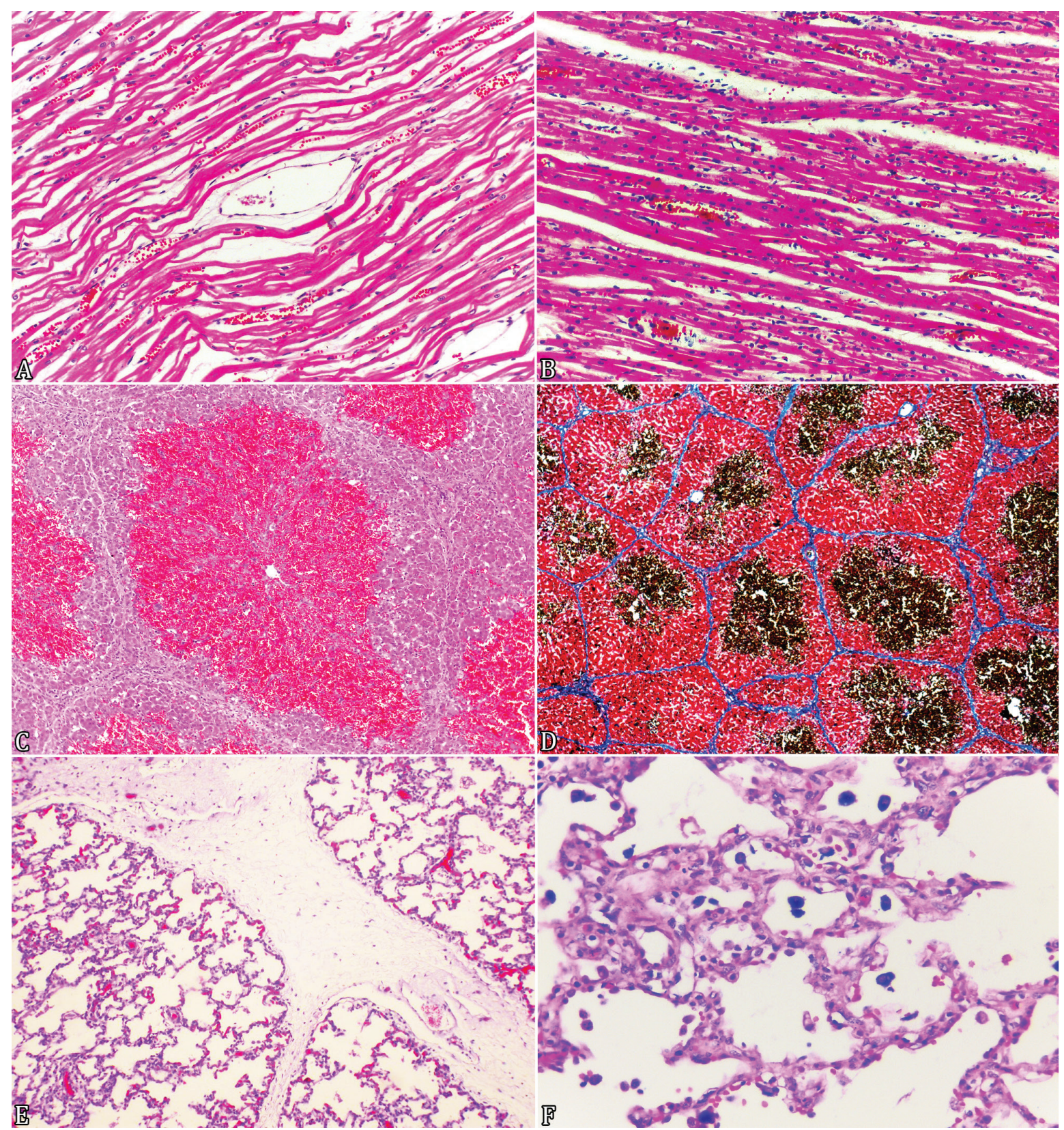

Fig.2. Histological features of nutritional dilated cardiomyopathy in pigs in Brazil. (A) Cardiomyocyte hypertrophy and attenuated wavy fibers in the myocardium. HE, obj.10x. (B) Cardiomyocytes of a control pig are arranged in homogenous parallel bundles. HE, obj.10x. (C) Moderate to marked hepatic congestion, degeneration and necrosis of the centrilobular hepatocytes (nutmeg liver). HE, obj.10x. (D) Moderate to marked centrilobular congestion (nutmeg liver). Masson's Trichrome, obj.10x. (E) Moderate interlobular pulmonary edema. HE, obj.10x. (F) Moderate numbers of macrophages with intracytoplasmic hemosiderin (heart failure cells) were evidenced within the alveoli. Perl's Prussian blue, obj.40x.

more studies are needed for clarification of this relationship in natural conditions. Additionally, high levels of iron were observed in the liver samples of the piglets with DCM, which likely occurred due to congestive heart failure and associated marked hepatic congestion.

In the outbreaks, the affected animals were mainly nursery piglets, which have a high energy requirement. External factors such as temperature, humidity, and facilities conditions, as well as factors related to diet, may interfere with the intake and utilization of food (Parsons et al. 1991, Berthol et al. 2001, Bunzen et al. 2008, Ramirez \& Karriker 2012). In two of the farms (B and C), the soybean meal had poor quality, with low urea activity and low solubility. A low solubility indicates that the soybean meal did not have the recommended water content, and it has possibly undergone a process called "over toasting" (Parsons et al. 1991, Berthol et al. 2001). The consumption of low solubility soybean meal by the nursery pigs probably resulted in decreased digestibility rates and a decrease in 
lysine availability, which most likely led to reduced weight gain (Parsons et al. 1991) However, the proteinogram of the low-solubility soybean meal, did not detect any abnormalities in the levels of amino acids. An hypothesis that these nutrients were absorbed in smaller amounts cannot be ruled out, since the nutritional value of protein in food does not solely depends on amino acids composition, but it also depends on digestibility and availability factors, which were not analyzed in this study (Bunzen et al. 2008).

HW:BW coefficient of the two piglets from the experimental study that had clinical signs and gross lesions were $0.86 \%$ and $0.73 \%$, which are almost twice the estimated mean value of pigs $(0.40 \%)$. In DCM, an increase of the heart chambers (mainly of the ventricles) is observed grossly, which acquire a rounded shape, with a flaccid appearance and a weight 20 to $50 \%$ above the normal range, as well as an increase in the HW:BW coefficient (O'Grady \& O'Sullivan 2004, Robinson \& Robinson 2016). In this study, dilation was observed in all heart chambers, which is similar to that described in dogs and humans (Edwards 1987, Lobo \& Pereira 2002, O'Grady \& 0 'Sullivan 2004). While it differs from the previously reported data in cats, mostly involves the left ventricle (Turk 1983).

The gross findings observed in piglets with nutritional DCM in this study are similar to the features of cardiomyopathy caused by taurine deficiency in cats, genetic cardiomyopathy in dogs and humans, gossypol toxicosis in pigs and "round heart disease" in turkeys (Edwards 1987, Sisson \& Thomas 1999, O'Grady \& O'Sullivan 2004, Stenzel et al. 2008, Sobestiansky 2012). The histological lesions observed both in the natural and experimental cases are characteristic of a congestive heart failure due to dilated cardiomyopathy, with wavy fibers in the myocardium. These histopathological features are consistent with the pattern of lesions observed in DCM in dogs, humans, turkeys, and pigs (Edwards 1987, Tidholm \& Jönsson 2005, Stenzel et al. 2008, Collins et al. 2015).

There are few reports of DCM in pigs compared to humans and dogs, in which DCM is the main type of cardiomyopathy diagnosed (Sisson et al. 1999a, Lobo \& Pereira 2002, 0'Grady \& O'Sullivan 2004, Elliott et al. 2008, Shen et al. 2011). Similary to the present study, the "round heart disease" in turkeys has an unknown etiology and pathogenesis (Stenzel et al. 2008); additionally, mulberry heart disease, which is an important heart disease that affects nursery pigs and does not have a defined etiology. However macroscopic and microscopic lesions are different from these cases (Shen et al. 2011).

\section{CONCLUSION}

Clinical history, pathological features, laboratory tests, and the results of the experimental study demonstrated the outbreaks of congestive heart failure by nutritional DCM in nursery pigs. This study suggests that the condition is related to the consumption of low-quality soybean meals. However, the specific cause is yet unknown, and further research on swine nutritional DCM is necessary since pigs may contribute as experimental models in human heart diseases.

Acknowledgements.- We thank Dr. Kent Schwartz, Dr. Scott Radke, Dr. Steve Ensley and Paulo Henrique Elias Arruda of Iowa State University for performing the GC/MS test; Professors Fernando Rosado Spilki and Andréia Henzel of Feevale University for performing the PCR test for Enterovirus. The authors thank so much all colleagues who have helped in some way.
Funding.- The authors disclosed receipt of the following financial support for the research, authorship, and/or publication of this article: "Coordenação de Aperfeiçoamente de Pessoal de Nível Superior" (CAPES), process number 406416/2016-8, "Conselho Nacional de Desenvolvimento Científico e Tecnológico" (CNPq), process number 150386/2017-6 and "Fundação de Amparo à Pesquisa do Estado do Rio Grande do Sul” (FAPERGS), process number 17/255-000946-0.

Conflict of interest statement.- The authors declare no conflicts of interest with respect to publication of this manuscript. The authors received no specific grants from any funding agency in the public, commercial or not-for-profit sector for the preparation of this manuscript.

\section{REFERENCES}

Berthol T.M., Mores N., Ludke J.V. \& Franke M.R. 2001. Proteínas da soja processadas de diferentes modos em dietas para desmame de leitões. Revta Bras. Zootec. 30(1):150-157. <http://dx.doi.org/10.1590/S151635982001000100022>

Bünzen S., Rostagno H.S., Lopes D.C., Hashimoto F.A.M., Gomes P.C. \& Apolônio L.R. 2008. Digestibilidade do fósforo de alimentos de origem vegetal determinada com suínos em crescimento e terminação. Revta Bras. Zootec. 37(7):1236-1242. <http://dx.doi.org/10.1590/S151635982008000700014>

Collins D.E., Eaton K.A. \& Hoenerhoff M.J. 2015. Spontaneous dilated cardiomyopathy and right-sided heart failure as a differential diagnosis for hepatosis dietetica in a production pig. Comp. Med. 65(4):327-332. <PMid:26310462>

Czarnecki C.M. 1984. Cardiomyopathy in turkeys. Comp. Biochem. Physiol. 77(4):591-598. <http://dx.doi.org/10.1016/0300-9629(84)90169-5> $<$ PMid:6143637>

Edwards W.D. 1987. Cardiomyopathies. Hum. Pathol. 18(6):625-635. <http:// dx.doi.org/10.1016/S0046-8177(87)80364-7> <PMid:3596582>

Elliott P., Andersson B., Arbustini E., Bilinska Z., Cecchi F., Charron P., Dubourg O., Kühl U., Maisch B., McKenna W.J., Monserrat L., Pankuweit S., Rapezzi C., Seferovic P., Tavazzi L. \& Keren A. 2008. Classification of the cardiomyopathies: A position statement from the European society of cardiology working group on myocardial and pericardial diseases. Eur. Heart. J. 29(2):270-276. <http://dx.doi.org/10.1093/eurheartj/ehm342> $<$ PMid:17916581>

Harvey P.A. \& Leinwand L.A. 2011. Cellular mechanisms of cardiomyopathy. J. Cell. Biol. 194(3):355-365. <PMid:21825071>

Keene B.W., Panciera D.P., Atkins C.E., Regitz V., Schmidt M.J. \& Shug A.L. 1994. Myocardial L-carnitine deficiency in a family of dogs with dilated cardiomyopathy. J. Am. Vet. Med. Assoc. 198(4):647-650. <PMid:2019534>

Korpela H. 1991. Hypothesis: increased calcium and decreased magnesium in heart muscle and liver of pigs dying suddenly of microangiopathy (mulberry heart disease): An animal model for the study of oxidative damage. J. Am. Coll. Nutr. 10(2):127-131. <http://dx.doi.org/10.1080/07315724.1991. 10718136><PMid:2030254>

Lobo L.L. \& Pereira R. 2002. Cardiomiopatia dilatada canina. Port. Ciênc. Vet. 97:153-159.

Loynachan A.T. 2012. Cardiovascular and hematopoietic systems, p.189-193. In: Zimmerman J.J., Karriker L.A., Ramirez A., Schwartz K.J. \& Stevenson G.W. (Eds), Diseases of Swine. 10th ed. Wiley-Blackwell, Iowa.

Miller L.M. \& Gal A. 2017. Cardiovascular system and lymphatic vessels, p.561-616. In: Zachary J.F. (Ed.), Pathologic Basis of Veterinary Disease. 6th ed. Mosby Elsevier, St Louis. <http://dx.doi.org/10.1016/B978-0323-35775-3.00010-2>

O'Grady M.R. \& O'Sullivan M.L. 2004. Dilated cardiomyopathy: an update. Vet. Clin. N. Am., Small. Anim. Pract. 34:1187-1207. 
Opriessnig T., Yu S., Gallup J.M., Evans R.B., Fenaux M., Pallares F., Thacker E.L., Brockus C.W., Ackermann M.R., Thomas P., Meng X.J. \& Halbur P.G. 2003. Effect of vaccination with selective bacterins on conventional pigs infected with type 2 porcine circovirus. Vet. Pathol. 40(5):521-525. <http://dx.doi. org/10.1354/vp.40-5-521><PMid:12949409>

Pallarés F.J., Yaeger M.J., Janke B.H., Fernández G. \& Halbur P.G. 2002. Vitamin $\mathrm{E}$ and selenium concentrations in livers of pigs diagnosed with mulberry heart disease. J. Vet. Diagn. Invest. 14(5):412-414. <http://dx.doi. org/10.1177/104063870201400509> <PMid:12296394>

Parsons C.M., Hashimoto K., Wedekind K.J. \& Baker D.H. 1991. Soybean protein solubility in potassium hydroxide: in vitro test of in vivo protein quality. J. Anim. Sci. 69(7):2918-2924. <http://dx.doi.org/10.2527/1991.6972918x> $<$ PMid:1885400>

Ramirez A. \& Karriker L.A. 2012. Herd evaluation, p.5-17. In: Zimmerman J.J., Karriker L.A., Ramirez A., Schwartz K.J., \& Stevenson G.W. (Eds), Diseases of Swine. 10th ed. Wiley-Blackwell, Iowa.

Richardson P., McKenna W., Bristow M., Maisch B., Mautner B., O'Connell J., Olsen E., Thiene G., Goodwin J., Gyarfas I., Martin I. \& Nordet P. 1996. Report of the 1995 World Health Organization/International Society and Federation of Cardiology Task Force on the definition and classification of cardiomyopathies. Circulation 93(5):841-842.<http://dx.doi.org/10.1161/01. CIR.93.5.841 > <PMid:8598070>

Robinson W.F. \& Robinson N.A. 2016. Cardiovascular system, p.44-50. In: Maxie M.G. (Ed.), Jubb Kennedy and Palmer's Pathology of Domestic Animals. 6th ed. Saunders Elsevier, St Louis. <http://dx.doi.org/10.1016/ B978-0-7020-5319-1.00012-8>

Shen H., Thomas P.R., Ensley S.M., Kim W.I., Loynachan A.T., Halbur P.G. \& Opriessnig T. 2011. Vitamin E and selenium levelsare within normal range in pigs diagnosed with mulberry heart disease and evidence for viral involvement in the syndrome is lacking. Transbound. Emerg. Dis.
58(6):483-491. <http://dx.doi.org/10.1111/j.1865-1682.2011.01224. $\mathrm{x}><$ PMid:21518323>

Stenzel T., Tykalowski B. \& Koncicki A. 2008. Cardiovascular system diseases in turkeys. Pol. J. Vet. Sci. 11(3):245-250. <PMid:18942548>

Sisson D., O'Grady M.R. \& Calvart C.A. 1999. Myocardial diseases of dog, p.581-620. In: Fox P.R., Sisson D. \& Moise N.S. (Eds), Textbook of Canine and Feline Cardiology. 2nd ed. W.B. Saunders, Philadelphia.

Sisson D. \& Thomas W.P. 1999. Myocardial disorders, p.1406-1410. In: Ettinger S.J. (Ed.), Textbook of Veterinary Internal Medicine Expert Consult. W.B. Saunders, São Paulo.

Sobestiansky J. 2012. Intoxicação por minerais, produtos químicos, plantas e gases, p.553-580. In: Sobestiansky J. \& Barcellos D.E.S.N (Eds), Doenças dos Suínos. 2ª ed. Cânone Editorial, Goiânia.

Tidholm A. \& Jönsson L. 2005. Histologic characterization of canine dilated cardiomyopathy. Vet. Pathol. 42(1):1-8. <http://dx.doi.org/10.1354/ vp.42-1-1><PMid:15657266>

Turk J.R. 1983. Necropsy canine heart: a simple technique for quantifying ventricular hypertrophy and valvular alterations. Compend. Contin. Educ. Vet. 5:905-910.

Vecchia A.D., Fleck J.D., Comerlato J., Kluge M., Bergamaschi B., Da Silva J.V., Da Luz R.B., Teixeira T.F., Garbinatto G.N., Oliveira D.V., Zanin J.G., Van der Sand S., Frazzon A.P., Franco A.C., Roehe P.M. \& Spilki F.R. 2012. First description of Adenovirus, Enterovirus, Rotavirus and Torque teno virus in water samples collected from the Arroio Dilúvio, Porto Alegre, Brazil. Braz. J. Biol. 72(2):323-329. <http://dx.doi.org/10.1590/S151969842012000200013><PMid:22735140>

Vilcek S., Nettleton P. \& Paton D. 2003. Remarkable cross reaction of pan-Pestivirus PCR primers with poliovirus genome. J. Virol. Methods 114(2):167-170. <http://dx.doi.org/10.1016/j.jviromet.2003.08.003> $<$ PMid:14625052> 